\title{
Campylobacter subantarcticus sp. nov., isolated from birds in the sub-Antarctic region
}

\author{
Lies Debruyne, ${ }^{1}$ Tina Broman, ${ }^{2}$ Sven Bergström, ${ }^{3}$ Björn Olsen, ${ }^{4,5}$ \\ Stephen L. W. $\mathrm{On}^{6}$ and Peter Vandamme ${ }^{1}$
}

Correspondence

Lies Debruyne

Lies.Debruyne@UGent.be

\author{
${ }^{1}$ Department of Biochemistry, Physiology and Microbiology, Faculty of Sciences, Ghent University, \\ Ledeganckstraat 35, B-9000 Gent, Belgium \\ ${ }^{2}$ CBRN Defence and Security, FOI, Swedish Defence Research Institute, SE-901 82 Umeå, \\ Sweden \\ ${ }^{3}$ Department of Molecular Biology, Umeå University, SE-901 87 Umeå, Sweden \\ ${ }^{4}$ Department of Medical Sciences, Section of Infectious Diseases, Uppsala University, SE-751 85 \\ Uppsala, Sweden \\ ${ }^{5}$ Section for Zoonotic Ecology and Epidemiology, Department of Natural Sciences, Kalmar \\ University, SE-391 82 Kalmar, Sweden \\ ${ }^{6}$ Institute of Environmental Research and Science, Food Safety Programme, PO Box 29 181, \\ Christchurch, New Zealand
}

\begin{abstract}
Six Gram-stain-negative, spiral-shaped, microaerobic isolates were obtained during a sampling from wild birds in the sub-Antarctic region. Based on initial observations, these isolates were classified as Campylobacter lari-like. The isolates were further characterized by whole-cell protein and amplified fragment length polymorphism (AFLP) analysis, which revealed that they were distinct from C. lari and all other known species of the genus Campylobacter. Here, we present comprehensive phylogenetic, genomic and phenotypic evidence that these isolates represent a novel species within the genus Campylobacter, for which the name Campylobacter subantarcticus sp. nov. is proposed. The type strain is R-3023 ${ }^{\top}$ (=LMG $24377^{\top}=\mathrm{CCUG}$ $38513^{\top}$ ).
\end{abstract}

At the time of writing, the genus Campylobacter (Sebald \& Veron, 1963) comprises 20 species and 8 subspecies with validly published names, with species found in both man and a wide range of domestic and wild animals and birds. Species most often associated with captive or free-living wild birds, either asymptomatic or with disease symptoms, include Campylobacter lari subsp. lari and Campylobacter jejuni subsp. jejuni, Campylobacter coli, and ureasepositive thermophilic Campylobacter (UPTC) lari isolates (Waldenström et al., 2002, 2007). The more recently descibed species Campylobacter canadensis has been isolated exclusively from captive whooping cranes (Inglis et al., 2007). The presence of zoonotic species in wild birds may provide a

Abbreviation: AFLP, amplified fragment length polymorphism.

The GenBank/EMBL/DDBJ accession numbers for the $16 \mathrm{~S}$ rRNA gene sequences of LMG 24377', LMG 24374, LMG 24375 and LMG 24378 are AM933371, AM933372, AM933373 and AM933374, respectively. The GenBank/EMBL/DDBJ accession numbers for the hsp60 gene sequences of LMG $24377^{\top}$ and LMG 24374 are AM933375 and AM933376, respectively.

An UPGMA dendrogram of partial whole-cell protein SDS-PAGE profiles is available with the online version of this paper. reservoir for human-pathogenic species, either through direct contact or through contamination of the environment.

During a sampling of wild birds and fur seals at Bird Island $\left(54^{\circ} 00^{\prime} \mathrm{S} 38^{\circ} 02^{\prime} \mathrm{W}\right)$ in the South Georgian archipelago in 1996, a collection of Campylobacter isolates was obtained. Several of these isolates were initially designated C. larilike, based on biochemical similarities. Six of these isolates were included in the present polyphasic taxonomic study: three were isolated from grey-headed albatrosses (Diomedea chrysostoma), two from black-browed albatrosses (Diomedea melanophris) and one from a gentoo penguin (Pygoscelis papua). No isolates could be obtained from Antarctic fur seals, suggesting that this species is restricted to birds. Strains were examined by whole-cell protein SDS-PAGE, amplified fragment length polymorphism (AFLP) and 16S rRNA and $h s p 60$ gene sequencing. Phenotypic characteristics were determined, and relevant DNA-DNA hybridizations were performed.

In February/March 1996, faecal swabs were taken from 10 adult female and 40 female Antarctic fur seal pups (Arctocephalus gazella), 30 adult gentoo penguins, 50 macaroni penguin chicks (Eudyptes chrysolophus), 50 black- 
browed albatross chicks and 50 grey-headed albatross chicks. Faecal samples were collected using cotton wool swabs inserted into the rectum or cloaca. Samples were stored in a charcoal transport medium (Transwab, BioDisc, Solna, Sweden) at $5-10{ }^{\circ} \mathrm{C}$, transported to Sweden and cultured within three weeks. Samples were plated on Campylobacter selective medium [42.5 g Columbia agar base $1^{-1}$ (Becton Dickinson), $5 \%$ citrated horse blood, $10 \mathrm{mg}$ vancomycin $\mathrm{l}^{-1}, 2500 \mathrm{IE}$ polymyxin $\mathrm{B}^{-1}, 5 \mathrm{mg}$ trimethoprim $\mathrm{l}^{-1}$ ] and incubated for $48 \mathrm{~h}$ at $42{ }^{\circ} \mathrm{C}$ under microaerobic conditions. Colonies showing a Gram-stain-negative seagull-like cell morphology under light microscopy were subcultured onto Mueller-Hinton agar plates supplemented with 5\% horse blood. Samples were stored at $-80{ }^{\circ} \mathrm{C}$ in trypticase soy broth supplemented with $15 \%$ glycerol.

Strains were cultured on Mueller-Hinton agar supplemented with $5 \%$ horse blood at $37{ }^{\circ} \mathrm{C}$ for $48 \mathrm{~h}$ under microaerobic conditions (approx. $4 \% \mathrm{O}_{2}, 6.5 \% \mathrm{CO}_{2}, 6.5 \% \mathrm{H}_{2}, 83 \% \mathrm{~N}_{2}$ ). DNA was extracted as described by Pitcher et al. (1989).

Protein extraction and SDS-PAGE were performed as described by Pot et al. (1994). For whole-cell protein SDSPAGE analysis, similarity of the normalized SDS-PAGE patterns obtained was determined by the Pearson product moment correlation coefficient, after which clustering was performed by UPGMA, using BioNumerics version 4.61 (Applied Maths, Belgium). For numerical analysis, a variable dense band region (36.1-43.2 kDa) (Vandamme et al., 1990) was excluded to increase species discrimination. The results of the numerical analysis, in combination with visual inspection of the SDS-PAGE patterns, demonstrated that the SDS-PAGE patterns of the novel species were distinct from those of $C$. lari, and all other known species of the genus Campylobacter (Supplementary Fig S1, available in IJSEM Online).

AFLP analysis was performed as described by Debruyne et al. (2009). After normalization, the AFLP profiles obtained were included in an in-house AFLP reference database, containing profiles from type and reference strains of all established species of the genus Campylobacter. The similarity between profiles was determined by the Pearson correlation coefficient, and cluster analysis was performed by UPGMA, using BioNumerics v 4.61. AFLP profiles from the six strains representing the novel species were divergent from those of strains of other species of the genus Campylobacter, and formed a distinct cluster (Fig. 1).

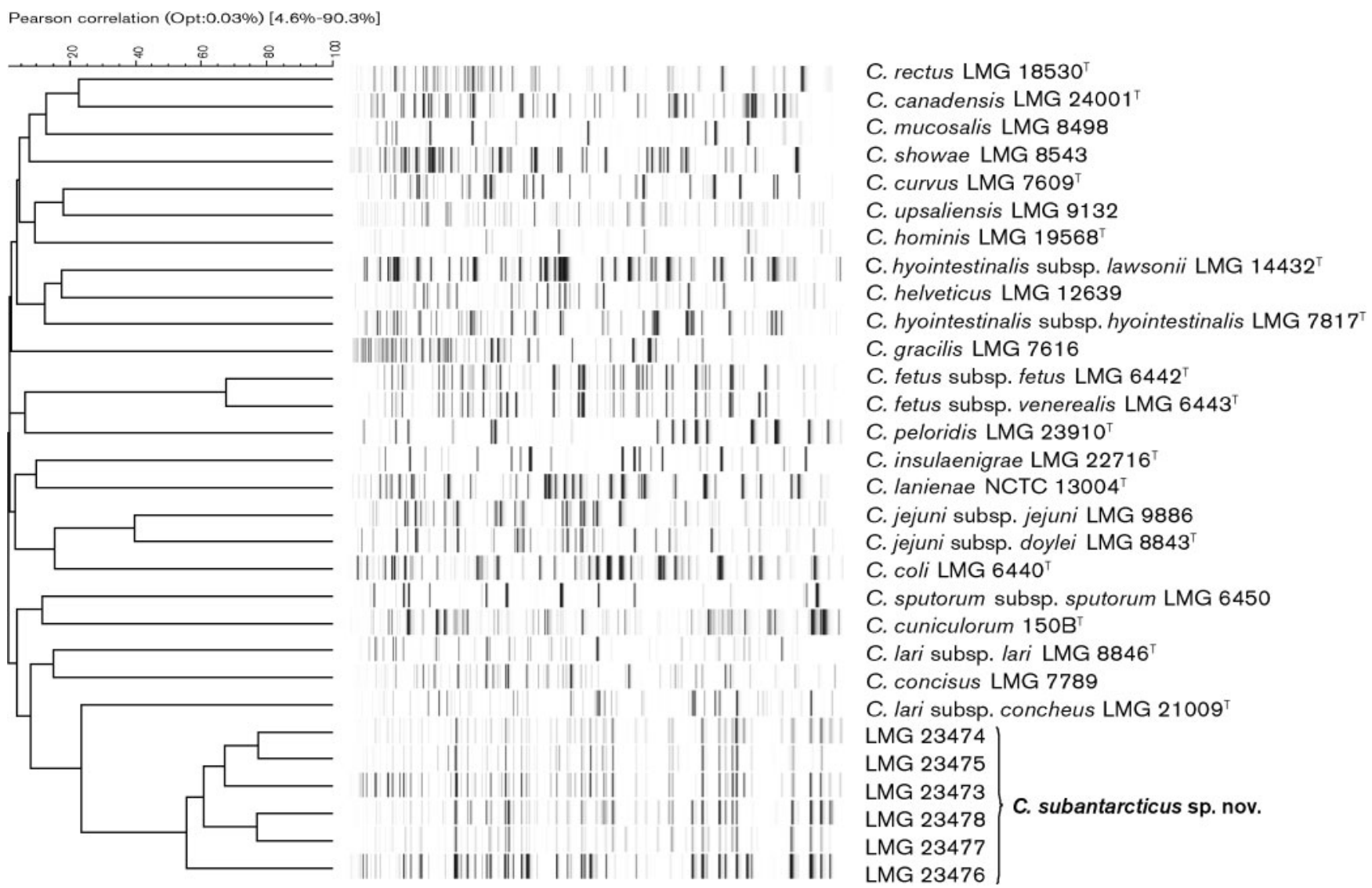

Fig. 1. Dendrogram representing the AFLP fingerprints of six strains representing the novel species Campylobacter subantarcticus sp. nov. and selected Campylobacter reference strains. Similarity was determined by the Pearson product moment correlation coefficient and clustering was performed by UPGMA. 
To support the delineation of the groups defined by the above genomic and proteomic analyses, phenotypic testing was performed according to the phenotypic identification scheme described by On et al. (1996), including 67 phenotypic characteristics. Methods for biochemical testing were as described previously (On \& Holmes, 1991a, b, 1992). The novel species belongs to the thermotolerant Campylobacter group, can grow in microaerobic conditions, and requires no hydrogen for growth. Differentiating characteristics are listed in Table 1, and a full phenotype description is given below.

To determine the phylogenetic position of the novel species, 16 S rRNA gene sequences of strains LMG 24374, LMG 24375, LMG $24377^{\mathrm{T}}$ and LMG 24378 (randomly selected) were determined as described previously (Vandamme et al., 2006). Sequences were assembled using BioNumerics v 5.1. Comparison by the FASTA algorithm to the EMBL sequence database revealed that the nearest phylogenetic neighbours were Campylobacter lari subsp. concheus, C. lari subsp. lari, C. jejuni, C. coli, C. insulaenigrae and C. peloridis, all with similarity levels exceeding $97 \%$. Strains LMG 24375, LMG $24377^{\mathrm{T}}$ and LMG 24378 had identical 16S rRNA gene sequences ( $100 \%$ sequence similarity), while LMG 24374 was slightly more divergent $(99.5 \%)$. Sequences were aligned using the CLUSTAL_X software package (Thompson et al., 1997), and clustering was performed by the neighbour-joining method (Saitou \& Nei, 1987) using BioNumerics v 5.1. Unknown bases were discarded for the analysis. Bootstrap values were determined using 500 replicates (Fig. 2). Polymorphisms within the 16S rRNA gene were inadequate to distinguish among the novel taxon and C. lari subsp. concheus, with interspecies sequence similarities (99.4-99.9\%) being equal to or exceeding intraspecies sequence similarities (99.5-100\%). To improve species discrimination, partial $h s p 60$ gene sequences of LMG 24374 and LMG $24377^{\mathrm{T}}$ were determined as described previously (Debruyne et al., 2009). Kärenlampi et al. (2004) demonstrated that phylogeny based on the $h s p 60$ gene sequence, coding for the $60 \mathrm{kDa}$ heat-shock protein, was similar to that of the 16S rRNA gene. However, $h s p 60$ was found to provide a better resolution for species of the genus Campylobacter, with lower interspecies sequence similarities and high intraspecies sequence similarities. Pairwise comparison of $h s p 60$ gene sequences from the novel taxon and from C. lari subsp. concheus demonstrated a clear separation between intraspecies (100\%) and interspecies (93.3-93.9\%) sequence similarities, making species discrimination feasible (Fig. 3).

For the determination of $\mathrm{G}+\mathrm{C}$ content, DNA was enzymically degraded into nucleosides as described by Mesbah \& Whitman (1989). The nucleoside mixture was separated by HPLC using a Waters SymmetryShield C8 column maintained at $37{ }^{\circ} \mathrm{C}$. The solvent was $0.02 \mathrm{M}$ $\left(\mathrm{NH}_{4}\right) \mathrm{H}_{2} \mathrm{PO}_{4}(\mathrm{pH} 4.0)$ with $1.5 \%$ acetonitrile. Non-methylated $\lambda$-phage DNA (Sigma) was used as the calibration reference. The DNA G+C content of strain LMG $24377^{\mathrm{T}}$ was $30 \%$, which falls within the range reported for members of the genus Campylobacter, i.e. 29-47\%.

Table 1. Phenotypic characteristics differentiating the novel strains from species of the genus Campylobacter.

Species: 1, Campylobacter subantarcticus sp. nov. (n=6); 2, C. canadensis; 3, C. coli; 4, C. concisus; 5, C. cuniculorum; 6, C. curvus; 7, C. fetus subsp. fetus; 8, C. fetus subsp. venerealis; 9, C. gracilis; 10, C. helveticus; 11, C. hyointestinalis; 12, C. hominis; 13, C. insulaenigrae; 14, C. jejuni; 15, C. lanienae; 16, C. lari subsp. concheus; 17, C. lari subsp. lari; 18, C. mucosalis; 19, C. peloridis; 20, C. rectus; 21, C. showae; 22, C. sputorum; 23, C. upsaliensis. +, All strains positive; -, all strains negative; ( +), 80-94\% strains positive; (-), 5-33\% strains positive; v, 35-67\% strains positive; ND, data not available. Additional data for reference species were taken from Inglis et al. (2007), Lawson et al. (2001), On et al. (1996) and Zanoni et al. (2009).

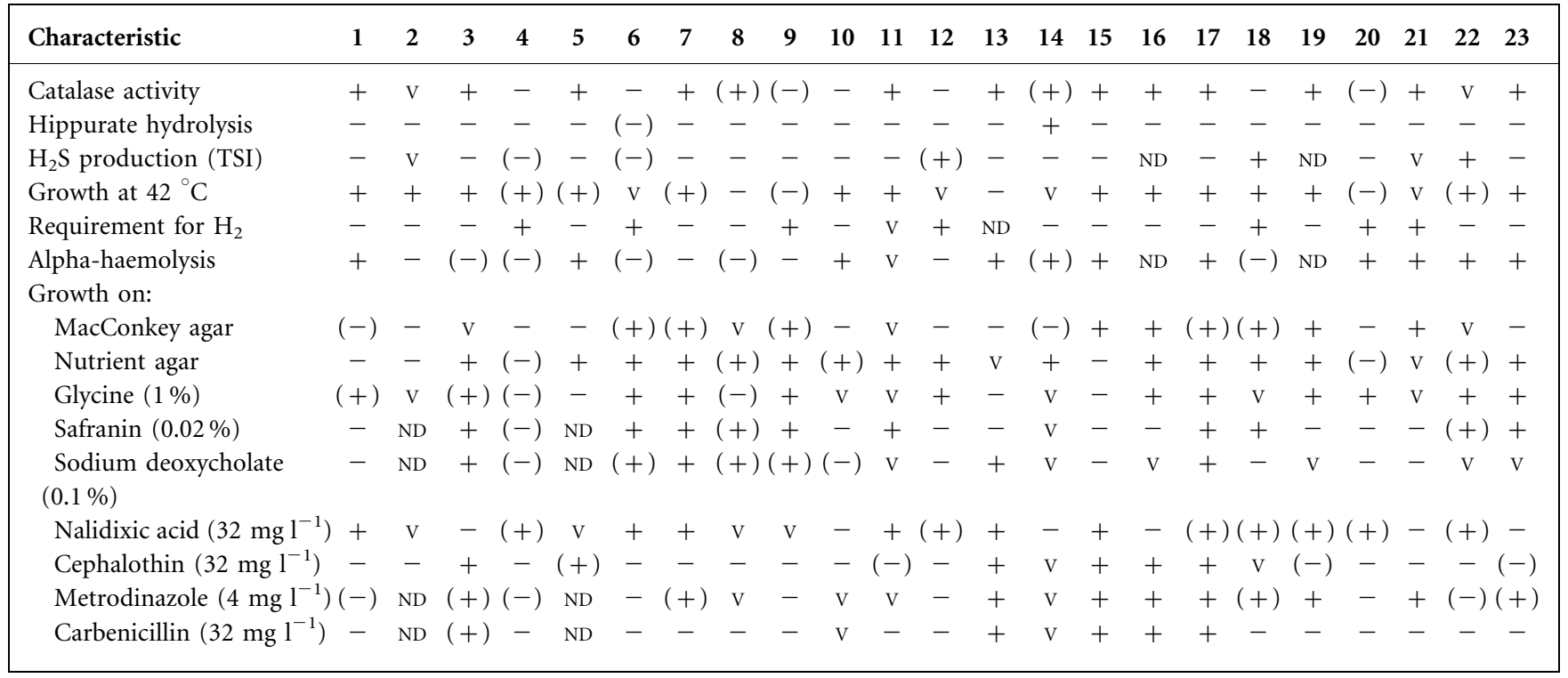




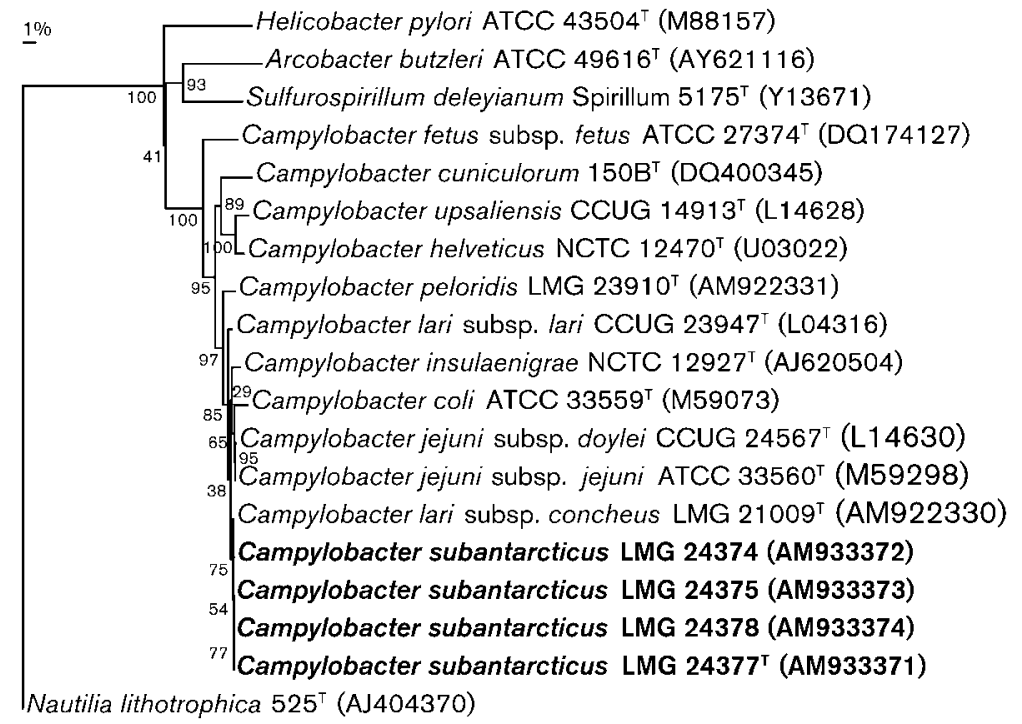

Fig. 2. Neighbour-joining tree based on $16 \mathrm{~S}$ rRNA gene sequences. Bootstrap values (\%) are indicated at the nodes. Bar, $1 \%$ sequence divergence.
DNA-DNA hybridizations were performed between strain LMG $24377^{\mathrm{T}}$ and type strains of its closest relatives, i.e. C. lari subsp. lari, C. lari subsp. concheus, C. peloridis, C. jejuni subsp. jejuni, C. coli and C. insulaenigrae. DNA was extracted from $0.25-0.5 \mathrm{~g}$ (wet wt) cells as described by Pitcher et al. (1989). DNA-DNA hybridizations were performed with photobiotin-labelled probes in microplate wells (Ezaki et al., 1989), using an HTS7000 Bio Assay Reader (Perkin Elmer) for the fluorescence measurements. The hybridization temperature was $30{ }^{\circ} \mathrm{C}$. Reciprocal experiments were performed for every pair of strains and standard deviation values ranged from $1-8 \%$. DNA-DNA hybridization values between strain LMG $24377^{\mathrm{T}}$ and the type strains of $C$. lari subsp. lari (LMG $8846^{\mathrm{T}}$ ), C. lari subsp. concheus (LMG $21009^{\mathrm{T}}$ ), C. peloridis (LMG 23910 ${ }^{\mathrm{T}}$ ), C. jejuni subsp. jejuni (LMG $8841^{\mathrm{T}}$ ), C. coli $\left(\mathrm{LMG} 6440^{\mathrm{T}}\right.$ ), and $C$. insulaenigrae (LMG $22716^{\mathrm{T}}$ ) were $57,55,38,21,16$ and $41 \%$, respectively. All of these values are well below the threshold of $70 \%$ for species delineation (Stackebrandt \& Goebel, 1994).

The present study demonstrates that the six bird isolates represent a novel species within the genus Campylobacter which can be distinguished from other species of this genus by whole-cell protein electrophoresis, AFLP fingerprinting, hsp60 gene sequence analysis and biochemical characteristics. We formally propose to classify these strains as Campylobacter subantarcticus sp. nov., with LMG $24377^{\mathrm{T}}$ as the type strain.

\section{Description of Campylobacter subantarcticus sp. nov.}

Campylobacter subantarcticus (sub.ant.arc'ti.cus N.L. masc. adj. subantarcticus pertaining to the sub-Antarctic region, from where the organism was first isolated).

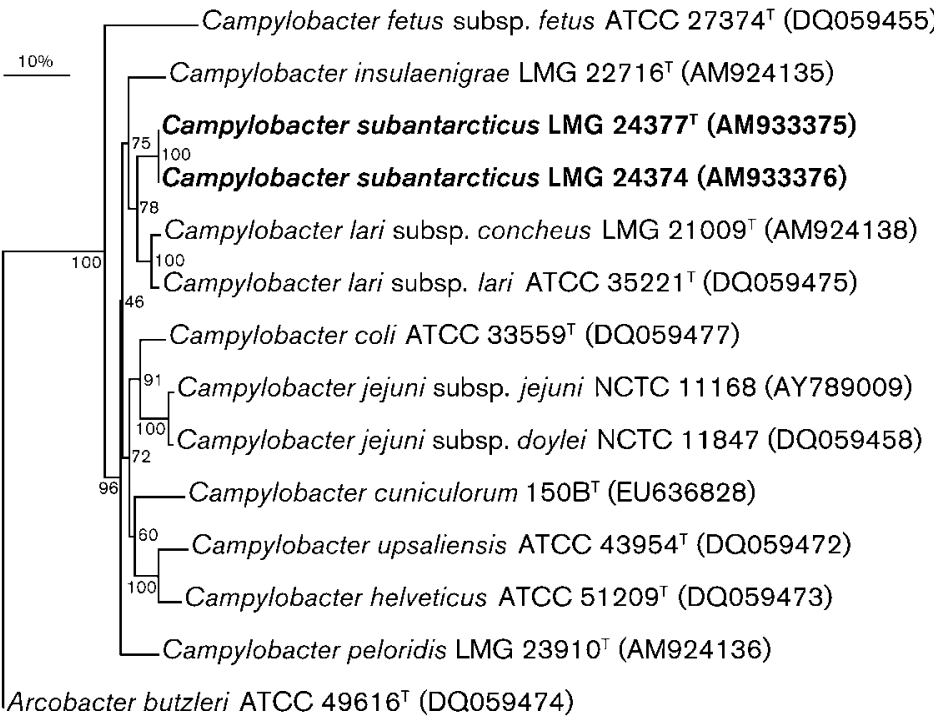

Fig. 3. Neighbour-joining tree based on partial $h s p 60$ gene sequences. All sequences are $555 \mathrm{bp}$ in length, with the exception of the sequence for $C$. cuniculorum, which is $489 \mathrm{bp}$ in length. Bootstrap values (\%) are indicated at the nodes. Bar, $10 \%$ sequence divergence. 
Cells are slightly curved, Gram-stain-negative rods. Colonies are colourless, round, entire, convex and 1$1.5 \mathrm{~mm}$ in diameter after culture on $5 \%$ blood agar for $72 \mathrm{~h}$ under microaerobic conditions. Single polar flagella are observed. Oxidase and catalase-positive. Does not hydrolyse hippurate or indoxyl acetate, and does not produce $\mathrm{H}_{2} \mathrm{~S}$ on TSI agar. Selenite is not reduced. Grows at $37{ }^{\circ} \mathrm{C}$ and $42{ }^{\circ} \mathrm{C}$, but not at room temperature $\left(18-22^{\circ} \mathrm{C}\right)$ or $25{ }^{\circ} \mathrm{C}$, under microaerobic conditions. No growth observed under aerobic conditions at either 37 or $25{ }^{\circ} \mathrm{C}$. Growth observed at $37{ }^{\circ} \mathrm{C}$ under anaerobic conditions on unsupplemented blood agar and on blood agar supplemented with $0.1 \%$ trimethylamine $\mathrm{N}$-oxide. Grows on media containing 1.0-2.0\% desiccated ox-bile, $2.0 \% \mathrm{NaCl}$, $32 \mathrm{mg}$ nalidixic acid $\mathrm{ml}^{-1}, 100 \mathrm{U} 5$-fluorouracil $\mathrm{ml}^{-1}$ and $0.05 \%$ sodium fluoride. Most strains grow on media containing $1 \%$ glycine. Most strains do not grow on media containing $4 \mathrm{mg}$ metronidazole $\mathrm{ml}^{-1}$ or on MacConkey agar. No growth observed on unsupplemented nutrient agar, casein agar, lecithin agar, tyrosine agar, or on media containing 0.02 or $0.05 \%$ safranin, $0.1 \%$ potassium permanganate, $0.005 \%$ crystal violet, $3.5-4.0 \% \mathrm{NaCl}$, $0.1 \%$ sodium deoxycholate, $32 \mathrm{mg}$ cephalothin $\mathrm{ml}^{-1}$ or $32 \mathrm{mg}$ carbenicillin $\mathrm{ml}^{-1}$. Alpha-haemolysis observed on $5 \%$ blood agar

Pathogenicity unknown. Strains have been recovered from wild birds in the sub-Antarctic region.

The type strain is $\mathrm{R}-3023^{\mathrm{T}}\left(=\mathrm{LMG} 24377^{\mathrm{T}}=\mathrm{CCUG}\right.$ $38513^{\mathrm{T}}$ ), which was isolated from a grey-headed albatross in 1996.

\section{Acknowledgements}

The expedition was supported financially by the Swedish Research Council FORMAS and the Swedish Polar Secretariat. We thank Jean Euzéby for help with naming the novel species. P.V. and L.D. are indebted to the Fund for Scientific Research Flanders (Belgium) for financial support.

\section{References}

Debruyne, L., On, S. W. L., De Brandt, E. \& Vandamme, P. (2009). Novel Campylobacter lari-like bacteria from humans and molluscs: description of Campylobacter peloridis sp. nov., Campylobacter lari subsp. concheus subsp. nov., and Campylobacter lari subsp. lari subsp. nov. Int J Syst Evol Microbiol 59, 1126-1132.

Ezaki, T., Hashimoto, Y. \& Yabuuchi, E. (1989). Fluorometric deoxyribonucleic acid-deoxyribonucleic acid hybridization in microdilution wells as an alternative to membrane filter hybridization in which radioisotopes are used to determine genetic relatedness among bacterial strains. Int J Syst Bacteriol 39, 224-229.

Inglis, G. D., Hoar, B. M., Whiteside, D. P. \& Morck, D. W. (2007). Campylobacter canadensis sp. nov., from captive whooping cranes in Canada. Int J Syst Evol Microbiol 57, 2636-2644.

Kärenlampi, R. I., Tolvanen, T. P. \& Hanninen, M. L. (2004). Phylogenetic analysis and PCR-restriction fragment length polymorphism identification of Campylobacter species based on partial groEL gene sequences. J Clin Microbiol 42, 5731-5738.
Lawson, A. J., On, S. L. W., Logan, J. M. J. \& Stanley, J. (2001). Campylobacter hominis sp. nov., from the human intestinal tract. Int $J$ Syst Evol Microbiol 51, 651-660.

Mesbah, M. \& Whitman, W. B. (1989). Measurement of deoxyguanosine/thymidine ratios in complex mixtures by high-performance liquid chromatography for determination of the mole percentage guanine + cytosine of DNA. J Chromatogr 479, 297-306.

On, S. L. W. \& Holmes, B. (1991a). Reproducibility of tolerance tests that are useful in the identification of campylobacteria. J Clin Microbiol 29, 1785-1788.

On, S. L. W. \& Holmes, B. (1991b). Effect of inoculum size on the phenotypic characterization of Campylobacter species. J Clin Microbiol 29, 923-926.

On, S. L. W. \& Holmes, B. (1992). Assessment of enzyme detection tests useful in identification of campylobacteria. J Clin Microbiol 30, 746-749.

On, S. L. W., Holmes, B. \& Sackin, M. J. (1996). A probability matrix for the identification of campylobacters, helicobacters and allied taxa. $J$ Appl Bacteriol 81, 425-432.

Pitcher, D. G., Saunders, N. A. \& Owen, R. J. (1989). Rapid extraction of bacterial genomic DNA with guanidium thiocyanate. Lett Appl Microbiol 8, 151-156.

Pot, B., Vandamme, P. \& Kersters, K. (1994). Analysis of electrophoretic whole-organism protein fingerprints. In Chemical Methods in Prokaryotic Systematics, pp. 493-521. Edited by M. Goodfellow \& A. G. O’Donnell. Chichester: Wiley.

Saitou, N. \& Nei, M. (1987). The neighbor-joining method: a new method for reconstructing phylogenetic trees. Mol Biol Evol 4, 406425.

Sebald, M. \& Veron, M. (1963). Base DNA content and classification of vibrios. Ann Inst Pasteur (Paris) 105, 897-910.

Stackebrandt, E. \& Goebel, B. M. (1994). Taxonomic note: a place for DNA-DNA reassociation and 16S rRNA sequence analysis in the present species definition in bacteriology. Int J Syst Bacteriol 44, 846849.

Thompson, J. D., Gibson, T. J., Plewniak, F., Jeanmougin, F. \& Higgins, D. G. (1997). The CLUSTAL_X windows interface: flexible strategies for multiple sequence alignment aided by quality analysis tools. Nucleic Acids Res 25, 4876-4882.

Vandamme, P., Pot, B., Falsen, E., Kersters, K. \& De Ley, J. (1990). Intra- and interspecific relationships of veterinary campylobacters revealed by numerical analysis of electrophoretic protein profiles and DNA:DNA hybridizations. Syst Appl Microbiol 13, 295303.

Vandamme, P., Holmes, B., Bercovier, H. \& Coenye, T. (2006). Classification of Centers for Disease Control group eugonic fermenter (EF)-4a and EF-4b as Neisseria animaloris sp. nov. and Neisseria zoodegmatis sp. nov., respectively. Int J Syst Evol Microbiol 56, 18011805.

Waldenström, J., Broman, T., Carlsson, I., Hasselquist, D., Achterberg, R. P., Wagenaar, J. A. \& Olsen, B. (2002). Prevalence of Campylobacter jejuni, Campylobacter lari, and Campylobacter coli in different ecological guilds and taxa of migrating birds. Appl Environ Microbiol 68, 5911-5917.

Waldenström, J., On, S. L., Ottvall, R., Hasselquist, D. \& Olsen, B. (2007). Species diversity of campylobacteria in a wild bird community in Sweden. J Appl Microbiol 102, 424-432.

Zanoni, R. G., Debruyne, L., Rossi, M., Revez, J. \& Vandamme, P. (2009). Campylobacter cuniculorum sp. nov., from rabbits. Int J Syst Evol Microbiol 59, 1666-1671. 